\title{
НАУЧЕН ЖИВОТ
}

\section{КАФЕДРА КУЛЬТУРОЛОГІЇ, РЕЛІГІЄЗНАВСТВА І ТЕОЛОГІЇ ЧЕРНІВЕЦЬКОГО НАЦІОНАЛЬНОГО УНІВЕРСИТЕТУ:КАМО ГРЯДЕШИ}

\author{
Микола Шкрібляк \\ доктор фрілософрських наук, доцент, \\ завідувач кафедри культурології, релігієзнавства та теології, \\ Чернівецький національний університет імені Юрія Федьковича \\ transcendere@ukr.net \\ ORCID 0000-0002-6036-5242 \\ DOI: https://doi.org/10.34017/1313-9703-2020-1(15)-2(16)-106-113
}

Проголошення державної незалежності у серпні 1991 року ознаменувало відродження національної богословської освіти та науки. Почали відновлювати своє функціонування духовні навчальні заклади, ліквідовані комуно-більшовицьким режимом. Не обминув цей процес й Буковину і, зокрема, Чернівецький університет, заснований у жовтні 1875 року австрійським імператором Францом Йосипом I (1848 - 1916) та названий на честь Його Величності.

Для чіткішого розуміння історичних передумов становлення та розвитку академічних богословських, а згодом і релігієзнавчих студій в Чернівецькому університеті варто нагадати, що сам цей вищий навчальний заклад розпочав роботу у складі трьох фракультетів Православно-Теологічного (офіційна повна назва - Греко-Східний Теологічний фракультет), Правознавчого та загально-політичних студій, і Філософрького фракультету (Чернівецький національний університет імені Юрія Федьковича. Імена славних сучасників, 2005, с. 23). Проте, Теологічний фракультет мав найкращі умови для розвитку та найвищі стандарти наукових студій і підготовки богословів з вищою університетською освітою, оскільки був заснований на базі Православного Інституту, або, як його називали сучасники, "Вищого Теологічного Семінару" (Буковина, її минуле і сучасне, 1956, с. 693), що діяв ще з 1827 р. під егідою Православної Церкви Буковини й своїм потенціалом та традиціями славився мало не в усій Центрально-Східній Європі, хоча сама Буковина в освітньому плані належала до найвідсталіших регіонів Австрійської Корони.

Видаючи грамоту про відкриття університету, австрійський імператор наголошував і сподівався, що університет буде "не лише храмом високої науки, вільних досліджень і здібностей людського розуму, але й благодатним вогнищем виховання страху Божого, високої моральності та благочестя; таким йому бути, розвиватися та процвітати і зростати на благо держави і краю" (Грамота Австрійського імператора Франца Йосипа про відкриття Чернівецького університету, 1875, арк. 3). Так і було, але не завжди.

Університет свою місію часто корегував в залежності від політичних режимів і світоглядно-ціннісних позицій тих, хто його очолював, входив до складу ректорату, керував факультетами тощо.

Між тим, найстрашнішим у житті Теологічного факультету, зрештою, й для інших двох був радянський період. Якщо Філософський і Правовий фракультет звели до ідеологічних кафедр (згодом було ліквідовано й правознавчі студії), то Теологічний факультет вирішили знищити до основ, а Резиденцію Митрополитів Буковини і Далматії з іiї Митрополичими палатами, Синодальною залою та Залою засідання Священного Синоду, Архів Консисторії і бібліотекою, а головне, храмами - митрополичою домовою церквою та Семінарською церквою Трьох Святителів - експлуатували в кращих традиціях радянської системи 
збереження унікальних пам'яток архітектури. Насправді все було розграбовано й розкрадено, а Резиденцію місцеві комуністи вирішили перетворити на "краєзнавчий музей" (Марусик, Коротун, 2019, с. 206, 213, 234, 240 та ін.).

Загалом про нищення цієї унікальної в краї архітектурної дивовижі з ії̈ величавими храмами написано багато монографій і статей. Усі вони - різні за інформативністю, рівним об'єктивності та насиченістю оціночних суджень. Але зрозуміло одне, що в ті часи, які дехто й по сьогодні трактує, як окупація Буковини - Австрійський, Австро-Угорський та Румунський період - це були найкращі часи для розвою богословських, i, загалом, релігієзнавчих студій на Буковині.

Новітнє відродження богословських і релігієзнавчих студій у Чернівецькому національному університеті зумовлене тими кардинальними суспільно-політичними трансформаціями, що відбувалися у Центрально-Східній Європі наприкінці 80-х років XX ст. й завершилися розпадом соціалістичного табору з його войовничою атеїстичною ідеологією. Національно свідома громадськість Буковини, що стала на шлях боротьби за церковну автокефалію одночасно поставила перед собою завдання відновлення Теологічного факультету в Чернівцях. Першим порушив це питання голова Буковинського крайового братства Андрія Первозванного, профессор Корнелій Товстюк. Для цього в жовтні 1991 р. вони зустрілися з Патріархом Мстиславом, який підтримав добру ініціативу й видав спеціальну благословенну грамоту та висловив запевнення про підтримку (в тому числі й фінансову) процесу відкриття у Чернівецькому університеті Теологічного факультету (ФТФ - осередок філософрсько-богословської освіти: культурно-просвітницька місія, 1875 - 1940; 1994 2019, с. 97).

Проте в силу об'єктивних та суб'єктивних чинників відновлення роботи відкладалося. I лише в жовтні 1993 р. Вчена рада університету проголосувала за відродження Теологічного факультету в Чернівецькому університеті. Але це рішення сприймалося по-різному. Тому на засіданні Вченої ради 29 грудня цього ж року було ухвалене нове рішення про відновлення функціонування в університеті і Філософського і Теологічного факультетів, але у складі єдиного Філософсько-теологічного факультету 3 кафедрою філософії та Теологічним відділенням. 3 цією назвою факультет у 2018 році відзначив своє 25-тиліття, а кафедра - 20-тиліття, здійснивши за чверть століття 22 випуски високоосвічених богословів і душпастирів, філософрів і релігієзнавців. Але цього року Вчена рада університету ухвалила рішення про його реорганізацію. Головною причиною стала недостатня кількість студентів денної форми навчання.

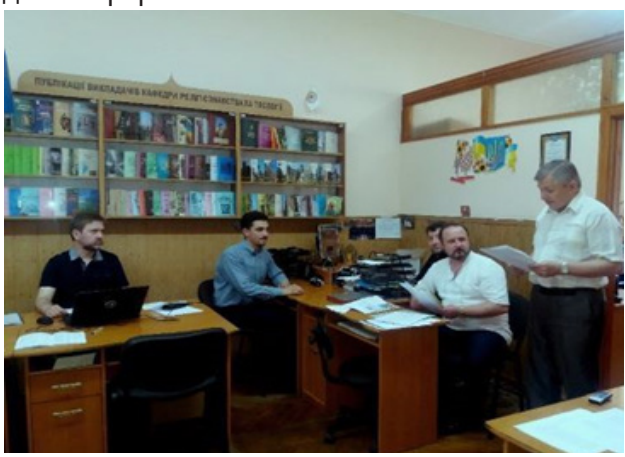

На фото (зліва направо): кандидат наук з богосл., к. іст. н., доцент, протоієрей Микола Щербань, к. філос. н., заст. декана з навчально-виховної роботи ФТФ Олександр Марчук, д. філос. наук, доцент, завкафедрою КРТ Микола Шкрібляк (сидять), д. іст. Н., професор кафедри КРТ Нестор Мизак (стоїть) - учасники науково-практичного семінару
Кафедра релігієзнавства та теології створена на підставі рішення ректорату та Вченої ради університету від 9 липня 1998 р. на базі Теологічного відділення. Ї̈̈ кадровий потенціал доповнили викладачі кафедри філософії та інших кафедр університету i, зокрема, Філологічного факультету.

Однією 3 передумов відкриття кафредри була невизначеність статусу теології та відмова держави вносити ії до переліку офріційно визнаних спеціальностей, що ставило під загрозу видачу дипломів студентам, які навчалися за цією спеціальністю. Шукаючи вихід з ситуації, що склалася, Патріарх Філарет звернувся 
до міністра освіти України М. Згуровського, щоб той невідкладно розглянув питання про внесення до державного переліку спеціальностей теологію, бо вже три роки тривало навчання за цією спеціальністю, наближався випуск, а питання про видачу дипломів випускникам і записом у них залишалося відкритим. Варто також усвідомлювати, що попри декларації про співпрацю з Церквою, ректорат був зацікавлений в тому, щоби кафедри релігієзнавства і теології, очолив світський науковець і педагог, оскільки вважав за доцільне звести до мінімум вплив на організацію навчально-освітнього процесу на філософсько-теологічному факультеті Митрополита Данила, котрий на початках, згідно з благословення Святійших Патріархів (Мстислава, Володимира та Філарета), а відтак і відповідно до Угод, укладених 3 університетом, виступав Замовником підготовки спеціалістів з теології.

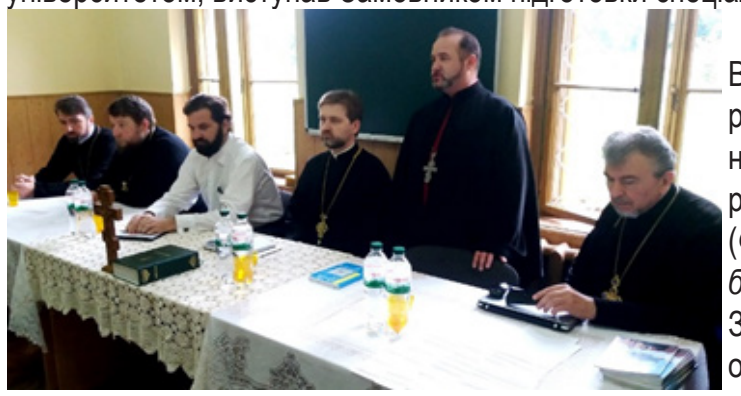

Зрештою, 9 липня 1997 р. Вчена рада університету ухвалила рішення про відкриття другої кафедри на фракультеті. По суті, йшлося про реорганізацію теологічного відділення (ФТФ - осередок фрілософськобогословської освіти ..., с. 100). Завідувачем кафедри було призначено одного 3 фундаторів і першого На фото (зліва направо): к. наук з богосл., протоієрей Микола Ма- декана філософського-теологічного русяк, К. наук з богосл., к. іст. н., методист ОП з Богослов'я, доцент, факультету доктора фолілософрських протоієрей Миколай Лагодич, к. фолол. Н., проректор з навчальної наук, профресора Миколу Сидоренка, Мирончук, Микола Щербань (сидять), Микола Шкрібляк (стоїть), під мудрим керівництвом якого доктор богословських наук, професор, ффундатор кафедри та ро розочався системний процес Михайло Марусяк - обговорення результатів підсумкової атестації формування кадрового потенціалу богословів 2018 p.

\section{науково-педагогічного}

колективу

кафедри, розробка основних напрямків дослідницької та навчально-освітньої діяльності. Професор Сидоренко головну увагу зосереджував на популяризації спеціальностей кафедри, а надто ж теології. Тому в перші роки її існування на факультет потягнулися студенти з сусідніх країні і передусім - Румунії.

Здобувачам богословської освіти навчальні предмети викладали провідні вчені та педагоги, серед яких професори - Семен Абрамович і Надія Бабич; священики з науковими ступенями - Василь Вепрук, Дмитро Садов'як і Василь Павенський, Михайло Марусяк, Микола Симчич; викладачі - Богдан Боднарюк, Галина Загайська, Любомира Мазурик та Марія Скаб та ін. Вони забезпечували читання найважливіших навчальних курсів: Священна історія Старого та Нового завітів, Фундаментальне богослов'я та апологетика, Літургіка та структура Православної Церкви, Риторика і гомілетика, Грецька та Латинська мови, Старо- та церковнослов'янська мови, Канонічне право, Візантологія та Історія давньої Церкви, Історія Церкви та релігійно-богословської думки в Україні, Моральне та Пастирське богослов'я, Аскетика і аскеза тощо. Важливою складовою навчального процесу було вивчення єврейської мови, викладання якої здійснювали головний рабин Чернівецької області Ноах Кофмманський, а також Ольга Щербак - завідуюча кабінетом івриту Чернівецької спеціалізованої школи I - III ст. №41., а іноземної (англ.) мови - улюблениця студентів Людмила Айгаре (ФТФ - осередок фрілософрько-богословської освіти ..., с. 104-105).

Варто наголосити, що формування кадрового потенціалу професорсько-викладацького складу і, зокрема, для читання лекцій для богословів за професора Сидоренка здійснювали спільно з Українською Православною Церквою Київського Патріархату. Лекції теологам читав сам Владика-ректор Димитрій (Рудюк), а також професор Дмитро Степовик. Так само було й з 


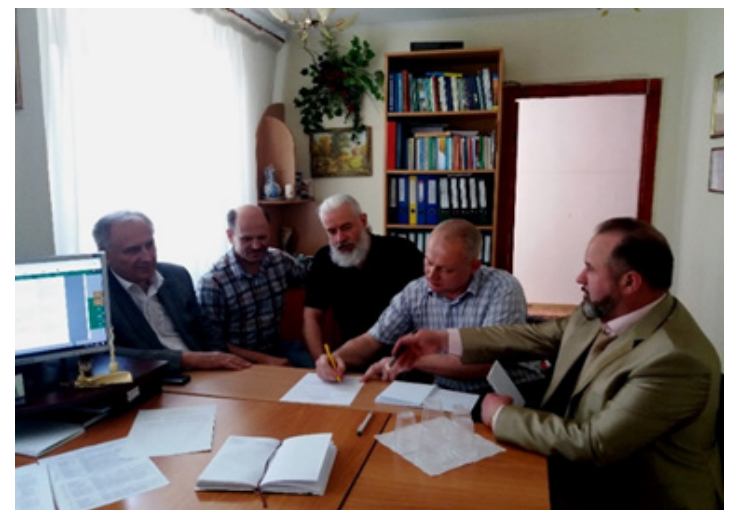

На фото (зліва направо): д. філос. н, профресор, завкафедрою релігієзнавства КНУ імені Т. Шевченка Євген Харьковщенко, д. філос. н, професор, завкафедрою філософії та релігієзнавства ЧНУ імені Богдана Хмельницького Олексій Марченко, д. філос. Н, професор кафедри філософії та релігієзнавства факультету гуманітарних наук Національного університету "КиєвоМогилянська академія" Сергій Головащенко, д. фрілос. н, завідувач кафедри фрілософії та релігієзнавства фракультету Східноєвропейського університету імені Лесі Українки Юрій Борейко, д. філос. наук, доцент, завкафедрою КРТ Микола Шкрібляк - під час засідання Навчально-методичгої комісії МОН України зі стандартизації релігієзнавчої освіти.

Бориса Починка. Його каденція тривала не цілий місяць та очільник кафедри докпадав зусиль, щоб вона мала надійні перспективи розвитку. Йому вдалося належно підготувати кафедру до початку нового навчального року, зміцнити її навчально-методичні можливості та імідж. Особливу увагу Борис Починок приділяв студентському самоврядуванню. Він запровадив інститут старостату й всіляко сприяв демократизації навчально-виховного процесу на факультеті і кафредрі зокрема.

28 вересня 2001 р. завідувачем кафедри релігієзнавства і теології ректор Степан Костишин призначив доктора історичних наук Василя Балуха (3 людьми і для людей ..., 2015, с. 41-42), який очолював її колектив упродовж п'ятнадцяти років (до січня 2016 р.). За цей час вдалося зміцнити кадровий потенціал кафедри, відкрити нову спеціальність культурологію, що обумовило потребу перейменування кафедри на: кафедру культурології, релігієзнавства та теології (01. 09. 2014 р.). За цей період колективу вдалося реалізувати два важливі науково-дослідницькі проекти: "Традиції, мистецтво, виховання - європейські цінності, цінності без кордонів" (спільно з Ботошанською духовною семінарією св. Георгія (Румунія) у рамках програми Євросоюзу, 2008 р.); "Роль етноконфесійних взаємовідносин транскордонних регіонів (Буковина, Галичина): суспільно-практичний вимір" (проект МOH України, 2015 - 2017 рр.). Під науковим керівництвом професора Балуха захистили наукові дисертації більше десятка кандидатів наук зі спеціальності "релігієзнавство" та три докторські дисертації (М. Шкрібляк (2015 р.), О. Бродецький (2017 р.), І. Горохолінська (2019 р.) - усі вони випускники філософсько-теологічного факультету.

У березні 2008 р., на базі кафедри засновано міжнародний часопис "Релігія та Соціум" (2008 р.), який з 2016 р. увійшов до науково метричної бази Index Copernicus, а також науковий журнал "Богословський вісник", якого маємо більше 20 чисел.

Зі вступом в дію Закону України “Про вищу освіту", який не дозволяє обіймати одній особі дві керівні посади та у зв'язку з захистом докторської дисертації зі спеціальності 09.00.11. - релігієзнавство з лютого 2016 р. кафедрою завідує Микола Шкрібляк. За цей період її колективу вдалося акредитувати спеціальність “культурологія", ліцензувати й 
акредитувати бакалаврську та магістерську освітні програми зі спеціальності 041 - богослов'я, а також науково-освітню програму з підготовки докторів філософії (PhD) зі спеціальності 031 - релігієзнавство, за якою здобувають наукові ступені як світські, так і духовні особи, в тому числі церковні ієрархи та пресвітери (єпископ Паїсій Кухарчук, протоієреї Іван Цихуляк, Андрій Квік та ін.).

Прикметно, що засадничим принципом керівництва кафедрою стала демократизація її організаційно-управлінської діяльності, паритетна участь та спільна відповідальність усіх учасників освітнього процесу за його здійснення й системне вдосконалення. Це дозволило підвищити якість внутрішнього забезпечення освітнього процесу, створити належні умови для професійного зростання науково-педагогічних працівників і набуття фрахових компетенцій здобувачами вищої освіти за випусковими спеціальностями кафедри, а також розширити їх доступ і можливості впливати на корегування навчально-освітнім процесом, проходженням стажування, обміну, наукової та навчальної мобільності, освоєння курсів з підвищення кваліфікації, виробничих практик тощо з метою трансформації науково-педагогічної діяльності викладачів, а для студентів їхньої освіти (як здобутої, так і в процесі її здобуття) на реально діючий соціальний і професійний ліфт, рейтингову оцінку.

Високий професійний науковий і навчально-освітній потенціал викладачів кафедри підтверджує їхня участь у роботі різного роду комісіях, комітетах Міністерства освіти і науки України, Національної агенції з оцінювання якості освіти тощо (І. Горохолінська, М. Лагодич, М. Шкрібляк, М. Щербань), спеціалізованих вчених радах (В. Балух, О. Бродецький, І. Возний, І. Горохолінська, М. Шкрібляк, М. Щербань), редакційних колегіях наукових журналів і часописів (В. Балух, О. Бродецький, М. Шкрібляк), в тому числі й зарубіжних видань (М. Чікарькова та ін.).

Викладачі кафедри часто виступають експертами з оцінки релігієтворчих процесів і соціокультурних трансформацій, а відтак і відповідності нормам українського законодавства діяльності тих чи інших конфесій та їхніх лідерів на теренах Буковини (В. Балух, О. Бродецький, І. Горохолінська, М. Шкрібляк, М. Щербань та ін.).

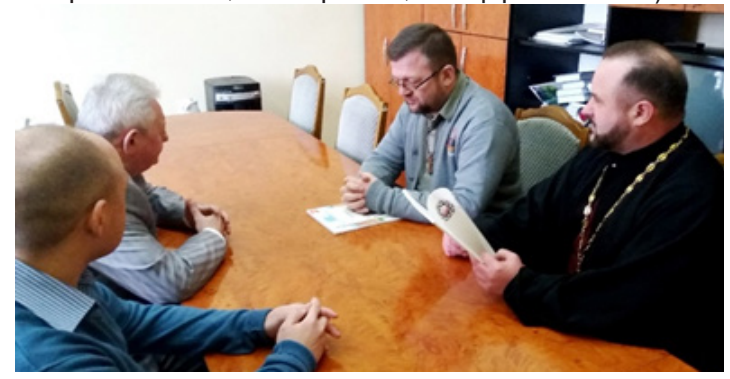

Іншим важливим досягненням стало відновлення за активної підтримки викладачів кафедри діяльності студентського науковопросвітницького і благодійницького товариства "Academia Ortodoxa" ("Відбулася презентація проекту діяльності відродженого студентського товариства "Academia На фото (зліва направо): д. філос. н, доцент, декан факультету Ortodóха"'”, online-ресурс), яке діяло Олександр Бродецький, д. іст. н, професор, перший проректор на Теологічному 31884 р. аж до наук, доктор богослов'я, завідувач кафедрою релігійних наук остаточної його ліквідації в 1944 р. Українського католицького університету протоієрей Василь Ру- Відкриття припало на особливий дейко д. філос. наук, доцент, завкафедрою КРТ Микола Шкрібляк Відкриття припало на особливий - під час засідання Навчально-методичгої комісії МОН України зі день в житті українського народу - 11 стандартизації релігієзнавчої освіти. жовтня 2018 р., коли було ухвалено рішення Священного Синоду Константинопольського Патріархату про надання Українській Православній Церкві автокефалії. Очолив організацію студент 5-го курсу Олег Луцан. У активах товариства - богословські читання, зустрічі, лекції-диспути, концерти, релігієзнавчі екскурсії та паломницькі місії, благодійницька та просвітницька діяльність, які здійснюються під душпастирською опікою протоієрея, доцента Миколая Лагодича. Так само ми пишаємося вокальним ансамблем "Менестрель”, який розвивається під духовною опікою к. іст. наук, ієрея Ігоря Луцана та к. фрілос. н., Олександра Марчука. 
Викладачі кафедри активно здійснювали і продовжують наукові пошуки, дбають про вдосконалення педагогічної майстерності, підвищення фахового рівня та впровадження в навчально-освітній процес інноваційних технологій та засвоєння передового досвіду компетентнісно зорієнтованих підходів до викладання та надання освітніх послуг. I хоча деякі з них уже не працюють на кафедрі, але свого часу саме вони найбільше попрацювали для зміцнення навчально-методичної бази кафедри, покращення й оптимізації навчальноосвітнього процесу загалом, підготовки найбільш творчо обдарованої студентської молоді до різного роду наукових заходів (конкурсів, олімпіад, вікторин, конференцій, семінарів, колоквіумів, конгресів і симпозіумів), де студенти спеціальностей кафедри - теологи, культурологи та релігієзнавці, - як їхні учасники здобували високі призові місця та нагороди.

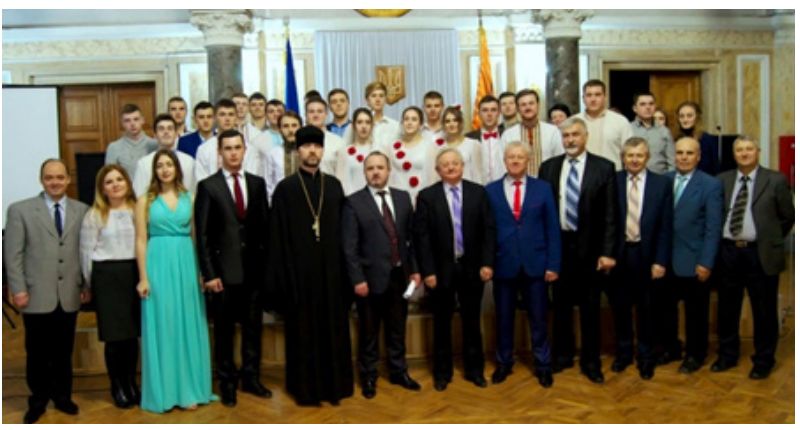

На фото - колектив викладачів і студентів філософсько-теологічного фа- Дл культету - учасників святкування 23-ої річниці з Дня його відродження у жовтні 1993 р. (зліва направо): Олександр Бродецький, Ірина Горохолінська, Діана Шоломейчук, Володимир Череп'юк, Миколай Щербань (зав. Богословським відділенням), Микола Шкрібляк (завкафедрою КРТ), Василь Балух (декан факультету), Віталій Докаш (завкафедрою соціології та місцевого самоврядування), Михайло Марчук (завкафедрою філософії), Нестор Мизак, Євген Скрипник, Володимир Пержун.

\section{Останніми}

роками колектив кафедри доклав чимало зусиль до популяризації власних науково-дослідницьких досягнень: відбулася низка презентацій монографій, навчальних підручників і словників. Це дозволило повернути навчальну дисципліну "Релігієзнавство", як вибіркову для вивчення на багатьох факультетах університету.

Високий рівень своєї інноваційної діяльності підтверджує те, що 2017 року кафедра посіла восьме місце в загально університетському

рейтингу, а серед кафедр гуманітарного циклу - перше. Професійні якості і можливості викладачів знайшли високу оцінку серед експертного середовища, органів місцевого самоврядування, силових відомств та громадських організацій, які стали частіше звертатися до кафедри за науковою експертизою і оцінкою суспільно-релігійних трансформацій, міжконфесійного діалогу, ролі церковно-релігійних, громадсько-культурних і політичних організацій у толерантизації стосунків між різними ентонаціональними та етнорелігійними меншинами, побудові громадянського суспільства та сучасних євроінтеграційних процесах України.

Колектив кафедри має цим пишатися, зокрема й тому, що її керівництво одразу обрало правильний шлях - тісної співпраці з Українською Православною Церквою Київського Патріархату, а сьогодні активно нарощуючи її з Православною Церквою України та Київською православною богословською академією. Результат цієї співпраці належно оцінила Вчена рада університету й Патріарху Філарету, як одному з їхніх фундаторів і благоукрасителів, присудили звання Почесного доктора Чернівецького національного університету імені Юрія Федьковича (“Патріарх Київський Філарет отримав звання Почесного доктора ЧНУ", online-ресурс).

Та, на превеликий жаль, уже декілька років поспіль не вдається організувати набір на спеціальність "релігієзнавство" за бакалаврським освітнім рівнем. Так само зменшилася кількість охочих навчатися і за спеціальністю "культурологія", оскільки держава різко зменшила обсяги державного замовлення за цими спеціальностями. Найкраща ситуація 3 набором в магістратуру на всі три спеціальності. Та попри реорганізацію факультету, доволі складні соціально-економічні умови і неоднозначне ставлення до гуманітарних світоглядно 
транслюючих наук і навчальних дисциплін, кафедра культурології, релігієзнавства і теології залишається провідною базою з підготовки докторів філософії за спеціальністю 031 - релігієзнавство у всьому західному регіоні України. I це - природньо, адже науковоосвітній процес тут базується на високих стандартах підготовки фахівців в галузі філософії, культурології, релігієзнавства та теології, авторських інноваційних технологіях досвідчених співробітників кафедри. Словом, не завдяки, а всупереч, але кафедра зберігає позитивну динаміку розвитку, вдосконалюючи зміст і форму наукової та навчально-освітньої діяльності.

Найбільшим досягненням є її випускники, серед яких - 7 архієреїв Православної Церкви України, 27 кандидатів наук, 4 доктори філософсььих наук, одна з яких - Ірина Горохолінська - здобула ще й ступінь доктора філософських наук за спеціальністю 041 - Богослов'я, ставши першою в Україні жінкою з докторським ступенем у богословській галузі знань. Таким же предметом гордості для кафедри залишаються назавжди понад 250 випускників-священнота церковнослужителів, більше 80 вчителів навчальних закладів різних рівнів акредитації та категорій, теле- й радіоведучих, кінорежисерів і драматургів, знаних і шанованих громадськокультурних та політичних діячів і управлінців, експертів, релігійних оглядачів і видавців. По суті, немає такої сфрери суспільного буття, де би не працювали випускники кафедри культурології, релігієзнавства та теології. Найбільше вони затребувані у загальноосвітніх школах, навчальних закладах різного рівня акредитації, державних установах (управліннях у справах релігії, відділах внутрішньої, молодіжної політики, силових структурах), консульствах, урядових і неурядових організаціях тощо (ФТФ - осередок фрілософрсько-богословської освіти ..., с. 125-127). Водночас, не можна утаїти тривоги і побоювання за майбутнє цього важливого осередку богословської та релігієзнавчої освіти і науки, що має славне і водночас драматичне минуле, а, очевидно, таке ж і майбутнє. Попри те, що тут був зосереджений надпотужний потенціал науковців і педагогів - 7 докторів наук, з яких 5 - професори і тринадцять кандидатів наук, більшість з яких - доценти, сьогодні колектив кафедри переживає не найкращі часи.

\section{Література та посилання}

Буковина, її минуле і сучасне (1956), під ред. Д. Квітковського, Т. Бриндзана, А. Жуковського, Зелена Буковина, Париж-Філадельфія-Детройт, 965 с.

"Відбулася презентація проекту діяльності відродженого студентського товариства "Academia Ortodóxa”'”, Електронний ресурс. Режим доступу (28.08.2020): https://www.bogoslov. cv.ua/index.php?id=2324\&action=art

"Грамота Австрійського імператора Франца Йосипа про відкриття Чернівецького університету". 30 вересня 1875 р., Державний архів Чернівецької області (ДАЧО), Ф. Р. - 216, Оп. 4, Спр. 54, Арк. 3.

3 людьми і для людей: науково-популярний нарис життєвого та творчого шляху Василя Олексійовича Балуха (2015), упорядн. М. В.Шкрібляк, Наші книги, Чернівці, 96 с.

Марусик, Т. В., Коротун, І. В. (2019), Архітектурне диво Чернівців, Букрек, Чернівці, 324 с. "Патріарх Київський Філарет отримав звання Почесного доктора ЧНУ", Електронний ресурс. Режим доступу (28.08.2020): https://shpalta.media/2018/06/23/patriarx-ki\%D1\%97vskijfilaret-otrimav-zvannya-pochesnogo-doktora-chnul

ФТФ - осередок фрілософьько-богословської освіти: культурно-просвітницька місія (1875 1940; 1994 - 2019), кол. монографія, гол. ред. Балух В.О., ЧНУ імені Ю. Федьковича, Чернівці, 288 с.

Чернівецький національний університет імені Юрія Федьковича. Імена славних сучасників (2005), ред. кол.: С. В. Мельничук та ін., Світ успіху, Київ, 288 с. 


\section{References}

Bukovyna, its past and present [Bukovy'na, yiyi my`nule i suchasne '](1956), ed. D. Kvitkovsky, T. Brindzan, A. Zhukovsky, Green Bukovina, Paris-Philadelphia-Detroit, 965 p.

"Presentation of the project of activity of the revived student society "Academia Ortodóxa"' ["Vidbulasya prezentaciya proektu diyal'nosti vidrodzhenogo students'kogo tovary`stva "Academia Ortodóxa"'], viewed 28 August 2020, available at: https://www.bogoslov.cv.ua/index. php?id=2324\&action=art

"Diploma of the Austrian Emperor Franz Joseph on the opening of Chernivtsi University" ["Gramota Avstrijs 'kogo imperatora Francza Josy pa pro vidkry 'ttya Chernivecz 'kogo universy`tetu"] September 30, 1875, State Archives of the Chernivtsi region (SAChR), F.R. - 216, Descr. 4 , File. 54, p. 3.

With people and for people: popular science essay on the life and career of Vasyl Alekseevich Balukh [Z lyud'my' i dlya lyudej: naukovo-populyarny 'j nary's zhy'ttyevogo ta tvorchogo shlyaxu Vasy`lya Oleksijovy`cha Baluxa] (2015), ed. M. V Skriblyak, Our books, Chernivtsi, 96 p.

Marusyk, T. V., Korotun, I. V. (2019), Architectural miracle of Chernivtsi [Arxitekturne dy'vo Chernivciv], Bukrek, Chernivtsi, $324 \mathrm{p}$.

"Patriarch Filaret of Kyiv received the title of Honorary Doctor of ChNU" ["Patriarx Ky' yivs 'ky”j Filaret otry mav zvannya Pochesnogo doktora ChNU"], viewed 28 August 2020, available at:: https://shpalta.media/2018/06/23/patriarx-ki\%D1\%97vskij-filaret-otrimav-zvannya-pochesnogo-doktora-chnu/

PhTF - the center of philosophical and theological education: cultural and educational mission [FTF - oseredok filosofs 'ko-bogoslovs 'koyi osvity': kul 'turno-prosvitny'cz'ka misiya] (1875 - 1940; 1994 - 2019), col. monograph, ch. ed. Balukh V. O, ChNU named after Yu. Fedkovych, Chernivtsi, 288 p.

Yuriy Fedkovych Chernivtsi National University. Names of glorious contemporaries [Chernivecz 'ky'j nacional'ny 'j universy 'tet imeni Yuriya Fed'kovy'cha. Imena slavny'x suchasny'kiv] (2005), ed.: Melnychuk S. V. and others, World of Success, Kyiv, 288 p.

\section{(c) Микола Шкрібляк}

